\title{
Granulomatous Reactions from Tattoos Following BRAF Inhibitor Therapy
}

\author{
Gabrielle Giet $^{\mathrm{a}}$ Eve Lebas $^{\mathrm{a}} \quad$ Andrée Rorive $^{\mathrm{b}} \quad$ Jorge E. Arrese \\ Arjen F. Nikkels ${ }^{a}$ \\ aDepartment of Dermatology, Liège University Hospital, CHU du Sart Tilman, \\ Liège, Belgium; 'bepartment of Medical Oncology, Liège University Hospital, CHU du Sart \\ Tilman, Liège, Belgium; 'Department of Dermatopathology, Liège University Hospital, \\ $\mathrm{CHU}$ du Sart Tilman, Liège, Belgium
}

\section{Keywords}

Tattoo $\cdot$ Granuloma $\cdot$ BRAF inhibitor $\cdot$ Dabrafenib $\cdot$ Adverse drug reaction

\begin{abstract}
BRAF inhibitors may present several cutaneous adverse effects, including actinic keratosis, squamous cell carcinoma, keratoacanthoma, rashes, increased photosensitivity, panniculitis, palmoplantar and capillary involvement, pruritus and xerosis as well as granulomatous reactions. A 30-year-old patient with multiple tattoos received dabrafenib and trametinib for metastatic melanoma. After 4 months, he developed an induration and thickening strictly limited to several tattoos. Histopathology revealed nonnecrotizing granulomas in the dermis. Topical steroids relieved pruritus but not the granulomatous aspect of the tattoos. As far as we know, this is the first description of granulomatous reactions restricted to preexisting tattoos following BRAF inhibitor therapy.




\section{Introduction}

BRAF mutations are found in $40-60 \%$ of melanomas [1, 2]. BRAF inhibitors like dabrafenib are routinely used in the treatment of advanced melanoma [3].

The combination of BRAF inhibitors with MEK inhibitors decreases the resistance to treatment and the adverse effects except pyrexia. In addition to pyrexia, the most common adverse effects are arthralgia, fatigue, and digestive disorders [1, 4]. Actinic keratosis, squamous cell carcinoma, and keratoacanthoma, rashes with variable presentations, increased photosensitivity, panniculitis, palmoplantar and capillary involvement, pruritus and xerosis are among the most frequently reported skin side effects [1,2]. Granulomatous reactions have been described in association with BRAF inhibitors [1-9] but, as far as we are aware of, no previous report exists on granulomatous reactions strictly limited to tattoos.

\section{Case Report}

A 30-year-old Caucasian patient, without any significant medical, allergologic or surgical history, presented initially with right neuralgia-like costal pain. After several months of misdiagnosis, a workup including angio-CT revealed a suspicious mediastinal mass of $5 \times 8 \mathrm{~cm}$ behind the right bronchus, parenchymal pulmonary micronodules, and a thickening of the diaphragmatic cupola with pleural and pericardial reactions. A PET-CT discovered a second right paravertebral focus and several suspect lymph nodes. A thoracoscopic biopsy was performed and a histopathological examination revealed the presence of a malignant tumor that did not express epithelial or lymphoid markers but expressed markers of soft and melanocyte tissues, including S100a, HMB45, NKIC3, and Melan-A. Furthermore, a BRAF v600e mutation was evidenced. The final diagnosis was metastatic melanoma.

A thorough dermatological examination was performed but no primary lesion was found. The patient presented a high number of halo nevi, suggesting that the primary lesion could have regressed.

The patient was a professional tattooist and his own cutaneous surface was extensively covered with different kinds of tattoos and colors.

After 4 months of combined treatment with dabrafenib (BRAF inhibitor) and trametinib (MEK inhibitor), he progressively developed an asymptomatic thickening and induration of several of his tattoos. There were no other skin signs. Clinically, the tattoos presented a 3dimensional appearance (Fig. 1) and were slightly itchy. The histopathological analysis of a cutaneous punch biopsy revealed the presence of a histiocytic infiltrate grouped into small, nonnecrotizing, narrowly confluent granulomas associated with the presence of abundant black pigmentary deposits, both intra- and extracellularly, with an exogenous appearance (Fig. 2a-c). Strong potency topical corticosteroids were prescribed with a partial improvement of the pruritus but no improvement of the infiltration of the tattoos. The main etiologies of pathologies leading to the formation of nonnecrotizing granulomas were excluded. Blood samples for ACE were negative. 


\section{Discussion}

Several cases of BRAF inhibitor-induced granulomatous cutaneous skin reactions have been reported in the literature. Table 1 summarizes the age and gender, the incriminated BRAF inhibitor, the time interval between the initiation of the BRAF inhibitor treatment and the cutaneous eruption and details the clinical aspects as well as the histological features of the reported cases.

Seven cases were associated with dabrafenib and one with vemurafenib. The mean age of the patients is 59.5 years and the gender ratio is 6 females $/ 3$ males. The mean time interval from the start of the BRAF inhibitor therapy is 5.75 months (min: 1.75 months, max: 9 months). All the cases presented lesions of the upper and/or lower extremities and only one case presented nodules on the trunk. The lesions were in general asymptomatic, tender to indurated, erythematous to brown papulo-nodules. The histological aspects were similar in all the reported cases, with nonnecrotizing granulomatous formations in the mid/deep dermis, composed of histiocytes, multinucleated giant cells and lymphocytes. In the majority of cases, an improvement could be observed under topical corticosteroids and anti-BRAF treatment could be continued. The pathogenesis still remains unclear.

This case presents granulomatous reactions restricted to the tattoos of the patient, explaining the granulomatous aspect. Probably, this phenomenon could respond to the Köbner effect, well known for granulomatous reactions [10]. On the other hand, granulomatous reactions have been described in tattoos [11]. However, in our patient, it is highly probable that the granulomatous reactions are associated with the BRAF inhibitor treatment as the patient had already had numerous tattoos for years. Another hypothesis could be the development of a rush phenomenon affecting several tattoos simultaneously, associated with joint pains, iritis, erythema nodosum, lung sarcoidosis, and scar sarcoidosis. Indeed, black tattoos have a 500 times increased risk of granuloma formation/sarcoidosis. Hence, in our patient the tattoo changes could also be attributed to a coincidental sarcoid development, triggered by the metastatic melanoma burden and/or the BRAF/MEK inhibitor therapy [12-14].

In conclusion, according to our knowledge, this is the first description of granulomatous reactions restricted to preexisting tattoos following BRAF inhibitor therapy.

\section{Acknowledgement}

G.G., E.L., A.R., J.E.A., and A.F.N. all provided significant contributions to the conception and design, the analysis and interpretation of the data, and to the drafting of the final article, revising it critically for important intellectual content, and they all gave final approval of the version to be published.

\section{Statement of Ethics}

The patient provided informed consent. 


\section{Case Reports in Dermatology}

Case Rep Dermatol 2019;11:101-107

DOI: $10.1159 / 000499959$

(C) 2019 The Author(s). Published by S. Karger AG, Basel www.karger.com/cde

Giet et al.: Granulomatous Reactions from Tattoos Following BRAF Inhibitor Therapy

\section{Disclosure Statement}

The authors have no conflicts of interest to declare.

\section{References}

1 Park JJ, Hawryluk EB, Tahan SR, Flaherty K, Kim CC. Cutaneous granulomatous eruption and successful response to potent topical steroids in patients undergoing targeted BRAF inhibitor treatment for metastatic melanoma. JAMA Dermatol. 2014 Mar;150(3):307-11.

2 Gençler B, Gönül M. Cutaneous side effects of braf inhibitors in advanced melanoma: review of the literature. Dermatol Res Pract. 2016;2016:5361569.

3 Flaherty KT, Puzanov I, Kim KB, Ribas A, McArthur GA, Sosman JA, et al. Inhibition of mutated, activated BRAF in metastatic melanoma. N Engl J Med. 2010 Aug;363(9):809-19.

4 Flaherty KT, Infante JR, Daud A, Gonzalez R, Kefford RF, Sosman J, et al. Combined BRAF and MEK inhibition in melanoma with BRAF V600 mutations. N Engl J Med. 2012 Nov;367(18):1694-703.

5 Leal L, Agut-Busquet E, Romani J, Sabat M, Yebenes M, Saez A, et al. Cutaneous granulomatous panniculitis and sarcoidal granulomatous papular eruption in a patient with metastatic melanoma treated with a BRAF inhibitor. J Dermatol. 2016 Jun;43(6):715-6.

6 Zimmer L, Hillen U, Livingstone E, Lacouture ME, Busam K, Carvajal RD, et al. Atypical melanocytic proliferations and new primary melanomas in patients with advanced melanoma undergoing selective BRAF inhibition. J Clin Oncol. 2012 Jul;30(19):2375-83.

7 Garrido MC, Gutierrez C, Riveiro-Falkenbach E, Ortiz P, Rodriguez-Peralto JL. BRAF inhibitor-induced antitumoral granulomatous dermatitis eruption in advanced melanoma. Am J Dermatopathol. 2015 Oct;37(10):795-8.

8 Green JS, Norris DA, Wisell J. Novel cutaneous effects of combination chemotherapy with BRAF and MEK inhibitors: a report of two cases. Br J Dermatol. 2013 Jul;169(1):172-6.

9 Ramani NS, Curry JL, Kapil J, Rapini RP, Tetzlaff MT, Prieto VG, et al. Panniculitis with necrotizing granulomata in a patient on BRAF inhibitor (dabrafenib) therapy for metastatic melanoma. Am J Dermatopathol. 2015 Aug;37(8):e96-9.

10 Camargo CM, Brotas AM, Ramos-e-Silva M, Carneiro S. Isomorphic phenomenon of Koebner: facts and controversies. Clin Dermatol. 2013 Nov-Dec;31(6):741-9.

11 Napolitano M, Megna M, Cappello M, Mazzella C, Patruno C. Skin diseases and tattoos: a five-year experience. G Ital Dermatol Venereol. 2018 Oct;153(5):644-8.

12 Serup J. Atlas of illustrative cases of tattoo complications. Curr Probl Dermatol. 2017;52:139-229.

13 Sepehri M, Hutton Carlsen K, Serup J. Papulo-nodular reactions in Black tattoos as markers of sarcoidosis: study of 92 tattoo reactions from a hospital material. Dermatology. 2016;232(6):679-86.

14 Kluger N. Sarcoidosis on tattoos: a review of the literature from 1939 to 2011. Sarcoidosis Vasc Diffuse Lung Dis. 2013 Aug;30(2):86-102. 


\section{Case Reports in Dermatology}

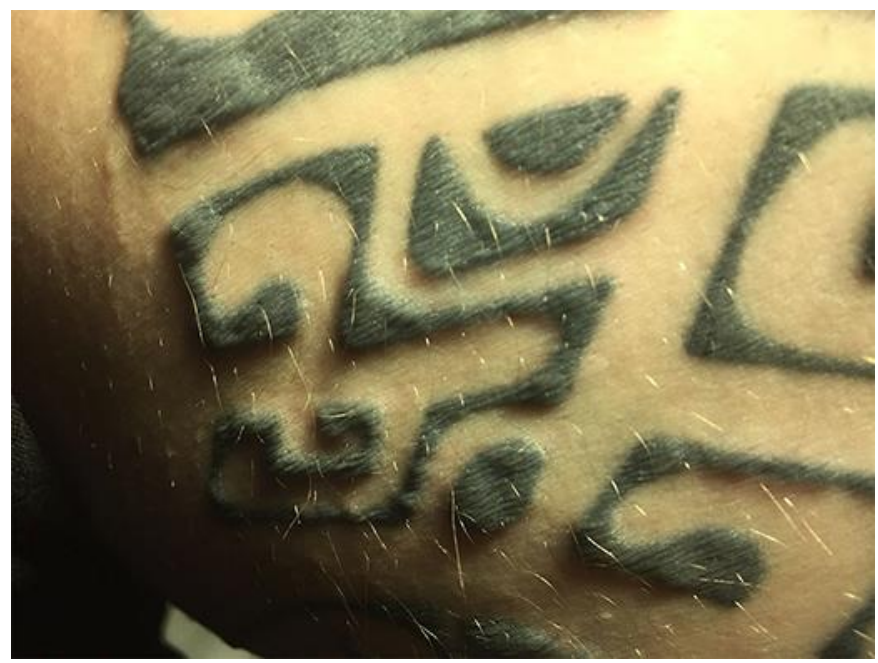

Fig. 1. A grazing light incidence clearly reveals the granulomatous aspect of the tattoos of the patient. 


\section{Case Reports in Dermatology}

Case Rep Dermatol 2019;11:101-107
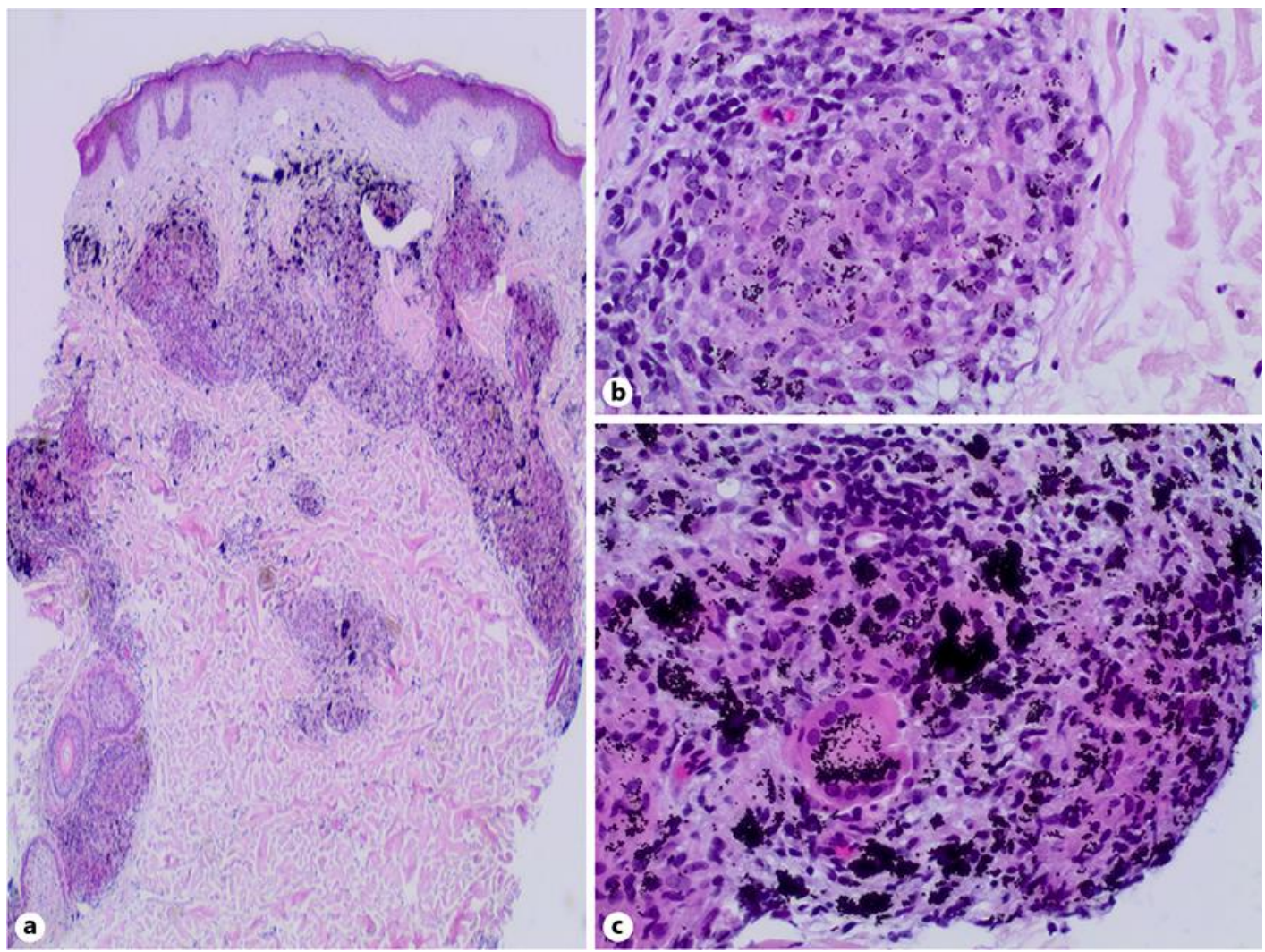

Fig. 2. a Dense granulomatous infiltrate of the superficial and mid dermis. Note numerous tattoo pigments $(\mathrm{H} / \mathrm{E}, \times 20)$. b Well-delimited nonnecrotizing granulomas with tattoo pigments $(\mathrm{H} / \mathrm{E}, \times 100)$. c. Tattoo pigments localized in both intra- and extracellular localizations of the nonnecrotizing granulomas. Some foreign-body giant multinucleated cells are observed $(\mathrm{H} / \mathrm{E}, \times 100)$. 
Table 1. Comparative table of BRAF inhibitor-induced granulomatous cutaneous skin reactions

\begin{tabular}{|c|c|c|c|c|c|c|}
\hline Ref & Sex & $\begin{array}{l}\text { Age, } \\
\text { years }\end{array}$ & $\begin{array}{l}\text { BRAF } \\
\text { inhibitor }\end{array}$ & $\begin{array}{l}\text { Time interval } \\
\text { before erup- } \\
\text { tion }\end{array}$ & Clinical aspect & Histological features \\
\hline 5 & $\mathrm{~F}$ & 41 & Dabrafenib & 8 months & $\begin{array}{l}\text { Erythematous subcutaneous nodules in } \\
\text { the upper and lower limbs }\end{array}$ & $\begin{array}{l}\text { Lobular panniculitis with lymphohistio- } \\
\text { cytic infiltrate organized into nonnecrotiz- } \\
\text { ing granulomas }\end{array}$ \\
\hline 6 & $\mathrm{~F}$ & 59 & Unspecified & 1.75 months & $\begin{array}{l}\text { Painful livid subcutaneous nodules on } \\
\text { the upper and lower extremities }\end{array}$ & $\begin{array}{l}\text { Septolobular panniculitis with neutrophilic } \\
\text { infiltrate and minor groups of other inflam- } \\
\text { matory cells included isolated noncaseat- } \\
\text { ing granulomas }\end{array}$ \\
\hline 1 & $\mathrm{~F}$ & 80 & Dabrafenib & 2 months & $\begin{array}{l}\text { Erythematous/violaceous, firm, } 1 \text { - to } 2 \text { - } \\
\text { mm papules and an erythematous, in- } \\
\text { durated 5-cm plaque on the right leg, } \\
\text { around the knee }\end{array}$ & $\begin{array}{l}\text { First biopsy: granulomas with hybrid sar- } \\
\text { coidal and foreign body type features encir- } \\
\text { cling and edematous and degenerated fo- } \\
\text { cus of the reticular dermis. No melanoma } \\
\text { cells identified } \\
\text { Second biopsy: metastatic melanoma with } \\
\text { a granulomatous response in the mid-retic- } \\
\text { ular dermis }\end{array}$ \\
\hline 1 & M & 70 & Vemurafenib & 5 months & $\begin{array}{l}\text { Multiple asymptomatic erythema- } \\
\text { tous/violaceous papules scattered over } \\
\text { bilateral upper and lower extremities }\end{array}$ & $\begin{array}{l}\text { Granulomas composed of histiocytes, Lang- } \\
\text { erhans-type multinucleated giant cells and } \\
\text { lymphocytes in the reticular dermis with } \\
\text { predilection to form around blood vessels }\end{array}$ \\
\hline 7 & M & 55 & Dabrafenib & 10 months & $\begin{array}{l}\text { Erythematous and slightly squamous } \\
\text { round plaques on upper trunk and on } \\
\text { left upper arm }\end{array}$ & $\begin{array}{l}\text { Granulomatous dermatitis in the superfi- } \\
\text { cial reticular dermis. } \\
\text { Admixed abundant melanophages from tu- } \\
\text { moral melanosis seen in one of the two } \\
\text { skin biopsies. No melanoma cells seen in } \\
\text { any of the specimens }\end{array}$ \\
\hline 8 & M & 72 & Dabrafenib & 7 months & $\begin{array}{l}\text { Nonpruritic, nontender, nonscaly, ery- } \\
\text { thematous papules and plaques on legs } \\
\text { and arms }\end{array}$ & $\begin{array}{l}\text { Interface dermatitis with increased dermal } \\
\text { mucin deposition with foci of sarcoidal- } \\
\text { type granulomas }\end{array}$ \\
\hline 8 & $\mathrm{~F}$ & 62 & Dabrafenib & 9 months & $\begin{array}{l}\text { A dark brown irregularly shaped mac- } \\
\text { ule on the right posterior shoulder }\end{array}$ & $\begin{array}{l}\text { Junctional nevus with lentiginous architex- } \\
\text { tural disorder and mild cytological atypia, } \\
\text { with focal underlying sarcoidal-type granu- } \\
\text { lomatous inflammation }\end{array}$ \\
\hline 9 & $\mathrm{~F}$ & 50 & Dabrafenib & 2 months & $\begin{array}{l}\text { Multiple, erythematous, indurated, ten- } \\
\text { der subcutaneous nodules bilaterally } \\
\text { on the anterior thighs, posterior arms } \\
\text { and left dorsal forearm without overly- } \\
\text { ing epidermal change }\end{array}$ & Panniculitis with necrotizing granulomas \\
\hline
\end{tabular}

